\title{
THE IMPLEMENTATION OF THE MULTIMEDIA APPROACH TO TEACHING BUSINESS ENGLISH
}

\author{
Olena Karpova \\ Odessa National Economic University, Odesa, Ukraine \\ karpova.e@oneu.edu.ua
}

\begin{abstract}
The paper deals with the problem of using multimedia technologies in teaching Business English at higher educational establishments. Modern forms, methods, and techniques of teaching Business English with multimedia tools have been considered. The author has outlined the components of the multimedia approach, its peculiarities and ways of using it in the classroom. Such methods of research as questionnaires, tests, quizzes, the pedagogical experiment and methods of mathematical statistics have been used. The author defines the multimedia technology as a type of a pedagogical technology that implies such organisation of an educational process that combines common forms, teaching methods and techniques with multimedia tools and products. Interactive methods and techniques, multimedia tools and multimedia products have been distinguished as the components of the introduced multimedia approach to teaching Business English. The results of the experiment have proved the efficacy of the implementation of the multimedia approach to teaching Business English at a higher educational establishment especially due to decreasing credits on obligatory disciplines and increasing hours given to out-of-class individual work of students.
\end{abstract}

Keywords: multimedia approach; Business English; interactive education; web-case; web-quest; interdisciplinary approach.

\section{Introduction}

Transformations in the system of education, challenges of the labour market and technological progress are setting new requirements for professional education in general and teaching Business English in particular.

In the National Doctrine on Education Development of Ukraine in the $21^{\text {st }}$ century (2001) it is mentioned that the priority of education development is the implementation of modern Information and Communication Technology that provides further improvement of teaching and educational processes, accessibility and efficacy of education, training young generation for further activity in the information society. Besides, in this document it is mentioned that the task is to train highly educated people, skilled specialists that are able to perform creatively, develop professionally and be ready to master and introduce new scientifically- and informationbased technologies. Thus, the aim of the government educational policy of Ukraine is training highly skilled staff that will be competitive in the fast-growing global information society.

The analysis of the theoretical literature showed that the problem of teaching students with multimedia technologies as well as a foreign language has been studied by many scholars (Bulakhova, 2007; Klevtsova, 2003; Kolesova, 2004; Collins, Brown \& Newman, 1987; Lazareva, 2007; Liaudis, 1984; Mayer, 2001; Tarnopolskyi, 2004). In modern methodology, the use of the Internet in the process of teaching a foreign language to students of non-linguistic universities is a means of information for tasks in project-based learning (Asoiants, 2008; Davydenko, 2007; Koval, 2008; Martyniuk, 2011; Naqvi, 2016; Ogurtsova, 2006; Petrova, 2006), individual work (Polat, 2000; Serdiukov, 1996; Sysoiev, 2008) and creation of virtual environment (Bigych, 2004; Krasnopolskyi, 2011).

Multimedia information technology is able to successfully summarise teaching experience, explore new methods and promote the optimisation of English teaching in colleges and universities (Li F., 2017). Moreover, technology-enriched classrooms integrate language teaching and learning inside the classroom or used for independent learning by students outside it (Naqvi, 2016).

Despite a great number of related methodical researches on teaching Business English and using multimedia technologies in education, the problem of using the multimedia approach to teaching Business English remains under-researched. Traditional forms and methods of teaching Business English are still not fully interactive, comprehensive, integrative and stimulating. First and foremost, it requires designing and implementing new approaches to teaching Business English at higher educational establishments. Due to decreasing credits on teaching disciplines and increasing hours given for out-of-class individual work, a teacher becomes no longer the main source of information but is gradually changing into a manager, consultant or expert of students' individual work. Thus, teaching Business English in the current condition of the transformation of the system of education in Ukraine needs effective means of teaching with the use of multimedia technologies that would have informative, forming, systematic, controlling and motivation functions.

The purpose of this article is to study modern methods and techniques of teaching Business English with multimedia technologies at higher educational establishments and to approve the efficiency of the multimedia approach experimentally. 
The implementation of multimedia technologies in the system of education changes forms, methods and tools of teaching Business English as well as creates real-to-life learning environment. The task of a teacher is to develop students' personality, to search for creative approaches to the organisation of the whole educational process and to select appropriate multimedia products and forms of teaching. Therefore, it is important to point out that the choice of reasonable multimedia products in the process of teaching Business English requires the use of multimedia programmes, trainings, e-books, online dictionaries and workbooks with MULTI-ROM as well as multimedia presentations and reports.

Having analysed traditional and modern methods and techniques to the interactive teaching of Business English, the following features can be outlined:

- mastering Business English is possible within a short period of time in case of the mobilisation of resources of personality and using its hidden power;

- Business English is not studied, it can be easier accepted through communication;

- communication matters but not learning grammar rules or texts;

- teaching foreign communication is taught in the form of a role-play and other interactive methods;

- multimedia technologies that imply the use of interadditive information technologies help foster the educational process and encourage students.

The analysis of psychological and pedagogical literature gave us an opportunity to define "the multimedia technology" as a pedagogical technology that implies such organisation of an educational process that combines common forms, methods and techniques of teaching with multimedia tools and products. It is important to point out that modern teaching technologies differ from traditional didactics by their psychological background because a teacher becomes an advisor, a manager or a mentor, who manages classroom and out-of-class activities in a totally different way.

Today teaching technologies and multimedia tools is an instrument of perception, comprehension, application, deduction and systematisation of new learning material. Besides, modern information technologies with their impact on personality development foster the implementation of differentiated or multilevel teaching of the English language taking into account students' abilities, needs and aspirations.

It should be mentioned that the multimedia approach can be characterised by projectability, integrity, practicability, assessment and efficacy that, all in all, contribute to definite progress and goals achieved as well as to time-saving, getting feedback, results assessment and failure correction.

Among the main methodical peculiarities of the multimedia approach to teaching Business English the following can be mentioned:

1. The traditional forms of teaching should be changed into interactive lectures, workshops and seminars conducted with multimedia technologies toward the introduction of on-line learning.

2. The implementation of multimedia technologies are to meet didactic and educational requirements.

3. The tasks should be interactive like educational video, Internet-based tasks, interactive games, webquests, etc.

4. The use of multimedia products includes the creation of e-textbooks, e-books, PowerPoint presentations, etc.

In our opinion, the advantages of realisation of the multimedia approach give an opportunity to update learning material regularly, share and copy it quickly, save a great amount of electronic information or data, place interactive web-elements as tests or an e-workbook as well as hyperlinks to literature given for extra reading in the e-libraries or websites of modern newspapers or magazines, etc. Therefore, it has become possible to combine both verbal and visual information to motivate students, activate their cognitive activity, improve their English ability and tune them in the educational process (Zhang R., 2017).

It is important to point out the fact that the introduction of the multimedia approach at higher educational establishments requires taking into account the peculiarities of physical and psychological background of students, their educational and cognitive abilities as well as didactic potential of multimedia technologies as a whole.

Therefore, we defined "the multimedia approach" to teaching Business English as an approach that consists in creation, application and definition of all the Business English teaching process and assimilation of knowledge by students due to the use of multimedia tools and products and their interaction that is aimed at optimisation of forms of teaching Business English.

Thus, the study of modern approaches and techniques to teaching Business English, the peculiarities of using multimedia in the educational process have helped us distinguish skills that should be formed to prepare students for future professional activity as well as outline the structure and components of the multimedia approach. 


\section{Method}

The pedagogical experiment was conducted at Odessa National Economic University from 2008 to 2014 and included three stages in order to measure the effectiveness of the realisation of the multimedia approach to teaching Business English that consisted in using interactive methods and techniques, multimedia tools and multimedia products within the whole educational process. The total amount of people that took part in the survey and in the experiment itself was 545 participants, among them there were 30 professors and 515 students (188 students participated in the formative experiment). Thus, the total amount of students in the experimental groups was 92 participants and in the control groups there were 96 students.

To study the current condition of teaching Business English with the multimedia approach and measure the level of English, the following methods of research as questionnaires, tests, quizzes, a pedagogical experiment, observation, consultations with teachers and students, methods of mathematical statistics have been used.

During the formative experiment on the basis of common forms of education, such as workshops, seminars, classroom and out-of-class individual work and group work, the multimedia approach was introduced.

One of the conditions of teaching Business English with multimedia technologies was having B2 level of English, basic informative preparation and computer literacy.

First of all, teachers and students (150 respondents) were offered a questionnaire on using multimedia technologies during the educational process, their effectiveness and drawbacks. The results showed that 53\% of teachers and $92 \%$ of students believed that the use of multimedia technologies fostered the development of creative thinking abilities, enriched the educational process as a whole, and helped students increase their level of English whereas only 8\% of students preferred traditional teaching methods.

One of the main problems of realisation of the multimedia approach was the lack of modern multimedia equipment or sometimes even its absence that prevented from creating and using multimedia products in teaching. The multimedia products that were popular among teachers and students were the following: multimedia presentations and educational video material (93\% of teachers), e-dictionaries and e-books (56\% of students), e-textbooks (60\% of teachers and only 19\% of students). According to the survey, $20 \%$ of students didn't use multimedia products during the whole learning process. The use of multimedia tools and products was occasional, not well organised, structured and systematic.

The questionnaire approved the effectiveness and the need to introduce the multimedia approach to teaching Business English.

To start with, we provided teaching Business English with the multimedia approach through the change of forms and methods of teaching focusing on students' differentiation, classroom and out-of-class individual work. So, the multimedia approach was realised through the conduct of multimedia mini-lectures, interactive seminars or workshops, web-quests and the creation and use of multimedia products such as multimedia presentations, electronic textbooks, etc. both by teachers and students.

The whole multimedia teaching system consists of two parts: the part of learning resource allocation and the part of English teaching activities. The first one means the material expanded from the traditional printed resources to audios, videos, animations and so on (Lou M., 2017).

The components of the multimedia approach to effective teaching of any discipline, including Business English, could be used at all stages of the educational process and can be presented in the following way:

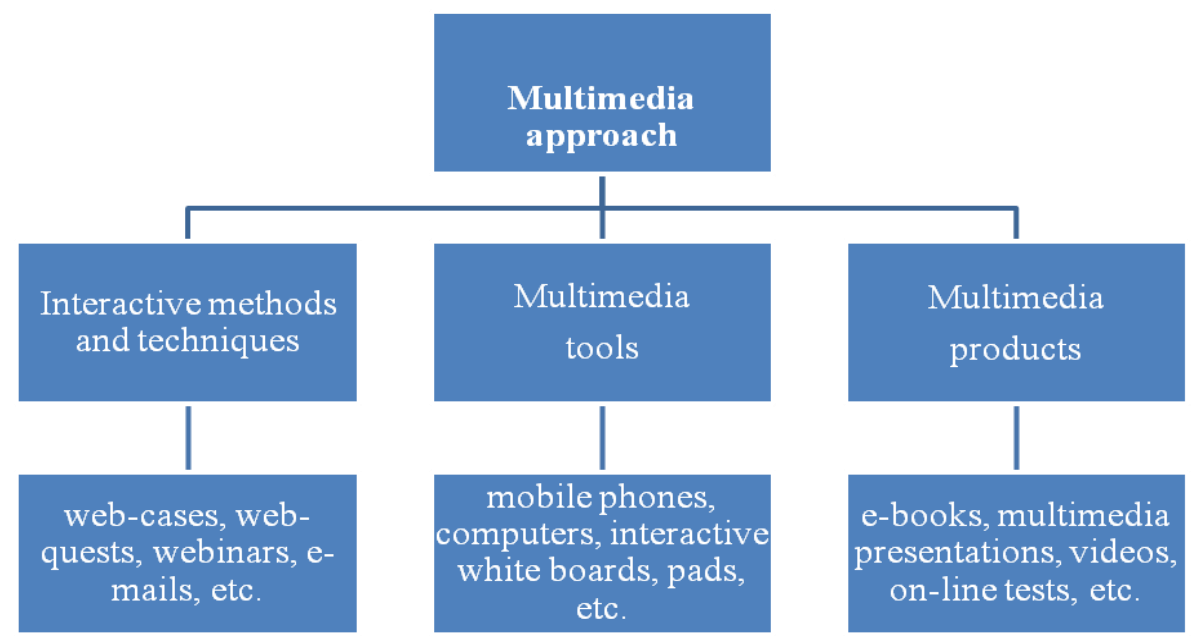

Figure 1. The components of the multimedia approach to teaching Business English 
As Figure 1 illustrates, the whole educational process was framed by the multimedia approach through interactive teaching methods and techniques that were realised and implemented along with multimedia tools and products.

Among many interactive methods, web-cases and web-quests were considered as the most reasonable ones for teaching Business English. For example, the use of web-quests in teaching Business English made the whole process interactive, resourceful and interesting. The lesson, conducted in the form of a web-quest, encouraged students to search for the necessary information on the Internet, develop analytical skills and acquire knowledge on the topic concerned as well as to broaden vocabulary with business terms. The webquest had the following elements: Introduction (problem-setting, motivation to solve the problem, timing), Task (clarification, instruction and links to online resources), the process of doing a web-quest and assessment (self-control, anonymous or written assessment, conclusions and feedback). Such criteria could be applied to the assessment of a web-quest as a multimedia presentation of the results obtained, timing and teamwork.

It should be mentioned that designing and implementing a web-quest requires taking into consideration the peculiarities of a discipline, the number of students in a group, the aim and tasks of the lesson. That is why a web-quest is a kind of a database of the discipline that gives students an opportunity to choose the direction of the research, analyse the problem selected and foster students to discuss their hypothesis and ideas (Dodge, 2001).

The advantages of a web-quest were as follows: time management skills development, formation of technological competence as well as research and data processing skills, teamwork skills. Among the drawbacks of this form of teaching we can mention orientation on students with a good level of English and uncontrolled amount of learning material acquired by students that is difficult to assess.

Teaching Business English is impossible today without using case studies. They are an excellent example of Collaborative Learning. The thing is that Cooperative Learning implies the formation of teamwork skills under the teacher's control whereas Collaborative Learning means no interference of a teacher into the process of doing tasks by teams (Johnson, 2008). We introduced a "web-case" that differed from a paper-based case in that all the material was presented on the website so that students could do the tasks online clicking on the links to the official websites of companies, electronic articles and other documents (http://oneu.edu.ua/businessenglish/). A web-case consisted of Background information about the companies, Problems to be solved, Tasks to be done and Writing an e-mail with a final decision of the team.

Before solving a web-case the students were divided into teams of 4 or 5 persons, they learnt the rules and started working. As a case study method implies collaborative learning, there was no teacher's guidance during the process. The students decided how to work, how to divide responsibilities and do the tasks themselves. The assessment criteria were timing, teamwork, a final decision.

In order to develop writing skills while teaching Business English, students were provided with the tasks that required writing business e-mails on the basis of the writing criteria of C1 level of CEFR that requires skills of writing business letters using complex grammar structures, idioms, clichés and professional vocabulary. The students learnt the rules and peculiarities of writing business e-mails, netiquette, namely the etiquette and culture of writing e-mails.

To develop speaking skills, we asked students to create PowerPoint presentations on economic and business topics, we engaged them in discussing video material, and we also used different interactive professionally-oriented games.

Teaching Business English with the multimedia approach, much attention was paid to out-of-class individual work that is one of the ways of mastering material out of the classroom (Mayer, 2001). It implied systematic work with educational material within a course as well as recommended literature, economic newspapers and books, revision for tests, etc. Besides, students wrote annotations to electronic articles and books, prepared reports or created multimedia presentations, solved web-cases, etc.

It is also important to emphasise the fact that the multimedia approach is not an approach that means a mix of the traditional teaching methods and a computer that will not lead to the formation of communicative competence, creative skills and the desire for self-education and self-realisation. Each multimedia product differs by its uniqueness, aim and application, and will be efficient under the condition of their complex use.

\section{Results}

One of the main indicators of the effectiveness of the multimedia approach was the level of English of students. To measure the students' progress, we offered them an entry test and a final test. Both tests with the four tasks were designed to measure four language skills - speaking, reading, listening and writing - and technical skills as well. 
According to the results of the pedagogical experiment, we found out that the number of students who had the Basic level of English decreased by 36,5\% in the experimental groups and only $13 \%$ in the control groups, as well as the number of students with Intermediate level of English, rose to $19,8 \%$ and 7,6\% in the experimental and control groups respectively. Finally, the number of students with the Advanced level of English in the experimental groups reached $16,7 \%$ whereas in the control groups it was 5,4\%.

Moreover, at the Basic level of English 15,6\% of the students in the experimental groups and $34,8 \%$ of the students in the control groups could read basic texts to study the course, analyse and search for necessary information on the Internet and work with e-textbooks; $18,8 \%$ and $41,3 \%$ of the students in both groups respectively could take notes, write a business letter or an essay on the given topic and $52,2 \%$ of the students in the control groups and $21,9 \%$ of the students in the experimental groups had the required speaking skills. $22,9 \%$ of the students in the experimental groups had listening skills at the Basic level of English whereas $45,6 \%$ of the students in the control groups had these skills formed as well.

At the Intermediate level of English 58,3\% of the students in the experimental groups and $45,7 \%$ of the students from the control groups could read and analyse a range of socio-economic articles, express their opinions on the problems concerned as well as $55,2 \%$ and $44,6 \%$ of the students in both groups respectively could write a business e-mail or present a multimedia presentation in a good way. Then, $52,1 \%$ of the students had the required listening skills and 55,2\% of the students could speak fluently and express their thoughts on professional situations clearly in the experimental groups at the given level while in the control groups $42,2 \%$ of the students had listening skills and 37,0\% of students had speaking skills at the level concerned.

Finally, 26,0\% of the students in the experimental groups had writing skills at the Advanced level of English as well as $25,0 \%$ of the students had listening and writing skills and 22,9\% of the students had speaking skills at the given level. In the control groups, only $14 \%$ of the students could write business emails at the Advanced level; 12,0\% of them had listening and reading skills; $10,9 \%$ of the students could communicate using business and economic terms, idioms, etc.

\section{Discussion}

Thus, the results obtained approved that today traditional teaching methods are becoming less efficient and slow down the process of digitalisation of education. The lack of multimedia tools and products as well as their rare and non-structured use in the educational process definitely affect the quality and speed of education. Though multimedia presentations, video material and interactive forms of teaching were sometimes used in the control groups, it didn't give the desired results because their usage was not regular, coherent, integrative and comprehensive within the whole educational process.

The implementation of the multimedia approach to teaching Business English helped us increase the level of English of the students in a more effective, useful and entertaining way as well as to form foreign professional communicative competence needed for future economists and managers.

The results also proved the idea that electronic discourse tends to be more lexically and syntactically more complex than oral discourse and features a broad range of linguistic functions beneficial for language learning. Moreover, the Internet creates optimal conditions for learning to write, since it provides an authentic audience for written communication and increases students' motivation (Warschauer, 2000).

It's also important to point out that the use of multimedia presentations helped us introduce much interesting information and cover more learning material and structure it; motivate students to learn the discipline; raise their level of English and measure their individual work; develop their learning abilities, apply knowledge and skills acquired during the educational process; and examine their readiness for their future profession.

The implementation of web-cases in teaching Business English contributed to preparing students for future professional activity through developing technical skills, critical and creative thinking, of course, teamwork skills. Though much time, technical skills or support from technical specialists and, of course, motivation and commitment of a teacher are required for designing and implementing web-cases and web-quests.

The results of the research have shown that the multimedia approach is a kind of a bridge from traditional ways of teaching to E-learning. The thing is that many traditional teaching methods are vanishing whereas online learning is difficult to implement in most developing countries at the moment. Therefore, the multimedia approach can be another step towards the creation of a new paradigm of education.

The problem that still remains is how to use the multimedia approach not only for teaching Business English but also other economic disciplines. Moreover, educational trainings or seminars should be conducted for teachers on how to use multimedia technologies in and out of the classroom.

Finally, it is important to point out the complexities that may occur when using the multimedia approach, namely, students' background, different levels of English and learning abilities, lack of technical 
skills, malfunction of hardware or software, etc. Therefore, students should be provided with all the necessary instructions, handouts and support from their teacher.

\section{Conclusions}

As the research results show, the introduction of the multimedia approach to teaching Business English through systematic and organised use of interactive teaching methods, multimedia tools and multimedia products helped increase the students' level of English in the experimental groups, broaden their knowledge and form teamwork skills.

Another important conclusion that has been made after the experiment is that successful realisation of the multimedia approach will not be effective unless there are modern equipment, methodical provision of the discipline, electronic database of learning material and, of course, motivated, qualified and creative teachers.

In conclusion, the analysis of scientific literature on teaching Business English and the use of multimedia in the educational process have shown that the problem is acute and needs to be researched. The paper doesn't completely cover all the aspects of the problem concerned. Further research needs to be carried out in this field in order to study the perspectives of teaching Business English on-line. Distance learning is becoming more popular and demanded nowadays, therefore, the problem of online learning and the ways of its realisation need to be studied thoroughly.

\section{References:}

Dodge, B. (2001). Creating A Rubric for a Given Task. Retrieved 10 May 2017 from http://webquest.org/sdsu/rubrics/rubrics.html

Johnson, D. W. \& Johnson R. T. (2008). Social Interdependence Theory and Cooperative Learning: The Teacher's Role. The Teacher's Role in Implementing Cooperative Learning in the Classroom, 1, 9-37. Springer Science+Business Media, LLC. https://doi.org/10.1007/978-0-387-70892-8_1

Li, F. (2017). The optimization of multimedia information technology in college English teaching. Agro Food Industry Hi-Tech, 28 (3), 467-471.

Lou, M. (2017). Design of English multimedia teaching system based on diversification theory. International Journal of Emerging Technologies in Learning, 12 (1), 119-129. https://doi.org/10.3991/ijet.v12i01.6488

Mayer, R. E. (2001). Multimedia Learning. NY : Cambridge University Press. https://doi.org/10.1017/cbo9781139164603

Natsional'na doktryna rozvytku osvity u XXI stolitti [National doctrine on education development in the $21^{\text {st }}$ century]. (2001). Osvita Ukrayiny, 1, 22-25.

Naqvi, S. (2016). ICT and language learning: A case study on student-created digital video projects. Journal of Cases on Information Technology, 18 (1), 49-64. https://doi.org/10.4018/jcit.2016010104

Warschauer, M., Shetzer H. \& Meloni, C. (2000). The Internet for English Teaching: Guidelines for Teachers. Alexandria, VA: TESOL.

Zhang, R. (2017). Research on design and implementation of English teaching platform based on campus network. Agro Food Industry Hi-Tech, 28 (3), 3538-3541. 